\title{
The Spread of Lindi (Liquid Garbage) of Benowo Garbage Landfill on Fish Pond Water Quality in Surabaya
}

\author{
$1^{\text {st }}$ Sulistinah \\ Departement of Geography Education \\ Faculty of Social Sciences and Law, \\ Universitas Negeri Surabaya \\ Surabaya, Indonesia \\ sulistinah@unesa.ac.id
}

\author{
$2^{\text {nd }}$ Kuspriyanto \\ Departement of Geography Education \\ Faculty of Social Sciences and Law, \\ Universitas Negeri Surabaya \\ Surabaya, Indonesia \\ kuspriyanto@unesa.ac.id
}

\author{
$3^{\text {rd }}$ Daryono \\ Departement of Geography Education \\ Faculty of Social Sciences and Law, \\ Universitas Negeri Surabaya \\ Surabaya, Indonesia \\ daryono@unesa.ac.id
}

\begin{abstract}
Benowo Garbage Landfill had an unexpected problem where Lindi (garbage liquid) pipe channel was leaking due to the activity of excavator to complete the project of garbage burning place. lindi (garbage liquid) pipe leaked on January 05, 2017 until March 15, 2017, but was not solved yet because of the rainy season and flood that made repairmen getting slow. The leak could not flow the garbage liquid completely which caused the leak partially sank into the soil and partly overflow to the area around leak point. The purpose of this study was to determine the spread of leak pollution and its impact on the fish pond around the leak point of Lindi (garbage liquid) pipe in Benowo Landfill. This research used descriptive quantitative research to describe the condition of leak of Lindi (garbage liquid) pipe impact Benowo garbage landfill to water contamination around fishpond helped by tests of laboratory and then analyzed. The sample in this research was fishpond water of $0 \mathrm{~m}-150 \mathrm{~m}$ distance from the leak point of Lindi (garbage liquid) pipe. This research variable was water quality of fishpond based on ph content which showed acid level in a solution and Chemical Oxygen Demand (COD) to see the size of the contamination level by organic material. The result was that the polluted water of fishpond from leak point of Lindi (garbage liquid) pipe after the $\mathrm{pH}$ and COD analyzed descriptively based on data obtained was a $25 \mathrm{~m}$ and $75 \mathrm{~m}$ to the north, $25 \mathrm{~m}$ to the east and from leak of Lindi (garbage liquid) pipe Benowo garbage landfill and caused water contaminated, death of fish at pond, watercolor changed into black, and the smell was not good. In short, the farther water distance with the leak point of the Lindi pipe TPA Benowo the smaller Lindi pollution or Lindi pollution is reduced.
\end{abstract}

Keywords - Fishpond Water Quality, Lindi pollution

\section{INTRODUCTION}

Garbage is all kinds of solid materials that discarded and considered to waste, it useless or disposable items due to excess. Garbage is expressed in the form of solid waste derived from human activities. Domestic garbage is dominated by organic materials although the composition of garbage varies from city to city even from day to day [1]
Final Disposal (TPA) is a solution to environmental pollution caused by garbage, a lot of the consequences that can be caused by garbage if not treated and not handled.

Living beings whether human, animal, or plant are potentially produced waste or garbage that increasingly accumulated over time and can disrupt the balance of the environment as well as being a source of disease.

The final disposal (TPA) that not properly managed will have an impact on the environment. Three important aspects of the environment they are soil, air, and water becomes the target of the negative impact of final disposal (TPA) [2]

TPA Benowo is experiencing unexpected problems that have been discovered pipeline leak Lindi Backhoe activity due to exposure in the process of settlement of the incinerator project. Lindi pipeline leaked on January 5, 2017, until March 15, 2017, which has not been resolved due to the rainy season that caused flooding so that is very slow repaired. The leak can't drain the liquor completely, causing some Lindi to sink in into the ground and some overflows into the area around the point of leakage of Lindi pipes.

TPA Lindi management of Benowo is good and managed using modern tools that have been applied from 2015 until now in 2017. Lindi management is processed through the Holding Tank, it works by take the Lindi then processed into clean water that repeatedly processed, before using this modern tool TPA Benowo used the alum, although after using this modern tool it used the Hydrogen Ion Lindi management, ie as Oxidizer so there is no residue so the sample results in the form of foam and then returned to the storage pond. 
Table 1. Garbage composition in surabaya

\begin{tabular}{cc}
\hline Garbage Composition & Percentage (\%) \\
\hline Wet garbage & 71,96 \\
Plastic & 12,94 \\
Paper and cardiboard & $5,35 \%$ \\
Diapers & $4,71 \%$ \\
Cable & $0,03 \%$ \\
Wood & $0,89 \%$ \\
B3 & $0.16 \%$ \\
Fabric & $1,94 \%$ \\
Glass & $0,92 \%$ \\
Rubber & $0,58 \%$ \\
Aluminum cans & $0,24 \%$ \\
Metal & $0,20 \%$ \\
Others & $0,08 \%$ \\
\hline
\end{tabular}

Source: Primary Data in the year 2017

Lindi garbage processing in TPA Benowo is used for its own purposes such as watering plants, washing heavy equipment and others because the water is nice and clean.

A serious problem at TPA Benowo is caused by untreated Lindi that hazardous and leach point leakage is located around the pond area. The condition is getting worse because the rainy season so to fix leaking lindi pipe is also takes a long time. The leakage condition of this pipe is getting worse because besides the repair process of leachate pipe this takes a long times not while the lindi that unprocessed is leaked more and more lindi out and overflow everywhere plus rain water so that exacerbate the condition and bad for the surrounding environment Ponds that exist around the leakage point of the Benowo waste TPA pipe.

Lindi water is a liquid of waste containing dissolved and suspended elements [3] water with a high concentration of organic content formed in Landfill due to rainfall entering into Landfill[4].

According to the Regulation of the Minister of Environment of the Republic of Indonesia Number 5 of 2014, water quality is a condition of water quality measured or tested based on certain methods and methods based on prevailing laws and regulations. Water quality standards are a measure of the extent or extent of living things, substances, energies, and pollutant elements that are tolerated in water.

Tabel 2. Klasifikasi Mutu Air Limbah Golongan C

$\begin{array}{lll}\text { Parameter } & \text { Satuan } & \text { Kadar } \\ \mathrm{pH} & - & 6-9 \\ \text { TSS } & \mathrm{Mg} / \mathrm{L} & 100 \\ \text { Sulfida } & - & 1 \\ \text { Amonia } & - & 5 \\ \text { Klor Bebas } & - & 1 \\ \text { BOD } & \mathrm{Mg} / \mathrm{L} & 100 \\ \text { COD } & \mathrm{Mg} / \mathrm{L} & 200 \\ \text { Minyak lemak } & - & 15 \\ \text { Sumber: [5] } & & \end{array}$

This study aims to determine the distribution of lindi pollution in the vicinity of lindi pipe leaks and lindi impacts on ponds around the location of lindi pipe leaks. Based on the context of the research in this study, the main focus of this study was "Distribution of lindi at Benowo Waste Disposal Site (TPA) Against the Water Quality of Surabaya City Pond".

\section{METHOD}

This type of research uses quantitative descriptive research. The research location is at the point of leakage of the final disposal site (TPA) Benowo lindi pipe. The sample in this research is pond water at a distance of $0 \mathrm{~m}-150 \mathrm{~m}$ from the lindi leaks pipe of TPA Benowo.

The research variable is the quality of the pond water. Pond water quality around the leakage point of lindi pipe of TPA Benowo is pond water quality based on $\mathrm{pH}$ content and Chemical Oxygen Demand (COD). $\mathrm{pH}$ indicates the level of acid or base in a solution while COD is the amount of oxygen needed so that the organic waste inside can be oxidized through chemical reactions. The COD value is a measure of the level of pollution by organic matter.

In this research the primary data was obtained from 8 points of pond water samples around the lindi leaked point at TPA Benowo. Data collection in this research uses techniques that are considered appropriate there is the measurement of laboratory tests, observation, and documentation. The analytical technique is descriptive or comparing the quality standard of class $\mathrm{C}$ wastewater based on the Regulation of the Minister of Environment of the Republic of Indonesia Number 5 year 2014 with the water quality that obtained from the field based on the analysis of Research and Industrial Development Agency of the Industrial Research and Development Center of Surabaya..

\section{RESULT AND DISCUSSION}

Before you begin to format your paper, first write and save the content as a separate text file. Complete all content and organizational editing before formatting. Please note sections A-D below for more information on proofreading, spelling and grammar.

Keep your text and graphic files separate until after the text has been formatted and styled. Do not use hard tabs, and limit use of hard returns to only one return at the end of a paragraph. Do not add any kind of pagination anywhere in the paper. Do not number text heads-the template will do that for you.

\section{A. Pond Water Quality Around Landfill According to $\mathrm{pH}$}

Table 3. Laboratory Test Results for Pond Water according to the $\mathrm{pH}$ content around the lindi leak point of TPA Benowo

\begin{tabular}{|c|c|l|l|l|}
\hline Sample Point & Parameter $(\mathrm{pH})$ & Unit & $\begin{array}{l}\text { Minister of } \\
\text { Environment } \\
\text { Regulation No. 5/2014 } \\
\text { (Group C) }\end{array}$ \\
\cline { 4 - 5 } & & & $\mathrm{pH}$ & Unit \\
\hline A1 & 8,0 & & $6-9$ & - \\
\hline
\end{tabular}




\begin{tabular}{|c|c|c|c|}
\hline A2 & 7,8 & \multirow{3}{*}{} & \\
\hline A3 & 7,5 & & \\
\hline B1 & 7,9 & & \\
\hline B2 & 7,7 & & \\
C1 & 7,6 & & \\
C2 & 7,6 & & \\
C3 & 7,2 & & \\
\hline
\end{tabular}

Source: Primary Data, 2017

The $\mathrm{pH}$ of pond water around Benowo TPA Laboratory test results in Table 3 is based on Minister of Environment Regulation No. 5/2014 (Group C) that pond water is still in the limits, so that water around the leakage point still can be used as a pond.

\section{B. Pond Water Quality Around Landfill According toCOD} Content

Table 4. Laboratory Test Results for Pond Water by COD Content

\begin{tabular}{|c|c|c|c|c|}
\hline \multirow[t]{2}{*}{$\begin{array}{l}\text { Sample } \\
\text { Point }\end{array}$} & \multirow[t]{2}{*}{$\begin{array}{l}\text { Parameter } \\
\text { COD }\end{array}$} & \multirow[t]{2}{*}{$\begin{array}{l}\text { Unit } \\
(\mathrm{mg} / \mathrm{l})\end{array}$} & \multicolumn{2}{|c|}{ 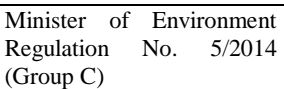 } \\
\hline & & & Parameter & Unit \\
\hline A1 & 558,93 & $\mathrm{mg} / / \mathrm{l}$ & \multirow{8}{*}{200} & \multirow{8}{*}{$\mathrm{mg} / \mathrm{l}$} \\
\hline $\mathrm{A} 2$ & 273,21 & $\mathrm{mg} / / \mathrm{l}$ & & \\
\hline A3 & 41 & $\mathrm{mg} / / \mathrm{l}$ & & \\
\hline B1 & 306,32 & $\mathrm{mg} / / 1$ & & \\
\hline $\mathrm{B} 2$ & 130,36 & $\mathrm{mg} / / 1$ & & \\
\hline $\mathrm{C} 1$ & 78 & $\mathrm{mg} / / 1$ & & \\
\hline $\mathrm{C} 2$ & 33 & $\mathrm{mg} / / \mathrm{l}$ & & \\
\hline $\mathrm{C} 3$ & 14 & $\mathrm{mg} / / 1$ & & \\
\hline
\end{tabular}

Sources : primary data 2017

Testing the pond water quality based on samples that tested by Laboratory Testing and calibration of Surabaya Industrial Baristand, the COD values there are 3 contaminated sample points and 5 sample points below the limit.

\section{Distribution of Lindi Pollution around TPA}

Table 5. Quality Of Water Pond On North Location Level Lindi Pipe TPA Benowo

\begin{tabular}{|c|c|c|c|c|c|}
\hline & \multirow{2}{*}{ Parameter } & \multirow{2}{*}{$\begin{array}{l}\text { Minister of } \\
\text { Environment } \\
\text { Regulation } \\
\text { No. 5/2014 } \\
\text { (Group C) }\end{array}$} & \multicolumn{3}{|c|}{ Laboratory Test Results } \\
\hline & & & A1 & A2 & $\mathbf{A 3}$ \\
\hline pH & pH & $6-9$ & 8,0 & 7,8 & 7,6 \\
\hline COD & COD & $200 \mathrm{mg} / \mathrm{l}$ & $\begin{array}{l}558,93 \\
\mathrm{mg} / \mathrm{l}\end{array}$ & $\begin{array}{l}273,21 \\
\mathrm{mg} / \mathrm{l}\end{array}$ & $\begin{array}{l}41 \\
\mathrm{mg} / \mathrm{l}\end{array}$ \\
\hline
\end{tabular}

Sources: primary data 2017

Table 5 show that the pond water quality in the north that ranged at $25 \mathrm{~m}, 75 \mathrm{~m}$, and $150 \mathrm{~m}$ from the lindi leaks in TPA Benowo (A1, A2, and A3) based on Minister of Environment Regulation No. 5/2014 (Group
C), some of them is not suitable to be used for aquaculture ponds. If based from the $\mathrm{pH}$ it show that the values is below the threshold, but in terms of the COD values is above the threshold.

Table 6. Pond Water Quality in the East Location of lindi Leakage Pipes TPA Benowo.

\begin{tabular}{|c|c|c|c|c|c|}
\hline & \multirow[t]{2}{*}{ Parameter } & \multirow{2}{*}{$\begin{array}{l}\text { Minister of } \\
\text { Environment } \\
\text { Regulation } \\
\text { No. 5/2014 } \\
\text { (Group C) }\end{array}$} & \multicolumn{3}{|c|}{ Laboratory Test Results } \\
\hline & & & B1 & B2 & B3 \\
\hline pH & pH & $6-9$ & 7,9 & 7,7 & - \\
\hline COD & COD & $200 \mathrm{mg} / \mathrm{l}$ & $\begin{array}{l}306,3 \\
2 \mathrm{mg} / \mathrm{l}\end{array}$ & $\begin{array}{l}130,36 \\
\mathrm{mg} / \mathrm{l}\end{array}$ & - \\
\hline
\end{tabular}

Sources: primary data 2017

Table 6 shows that the ponds water quality in the east of the leakage point of the lindi pipe of TPA Benowo to the distance of $75 \mathrm{~m}$, because at a distance of $150 \mathrm{~m}$ already used as a parking area of TPA Benowo and idle land that in the future will be build incinerator of TPA Benowo.

The $\mathrm{pH}$ and COD parameters, which are suitable are seen from the $\mathrm{pH}$ parameters while the COD parameters from $25 \mathrm{~m}$ distance are not suitable while the distance of $75 \mathrm{~m}$ is suitable but the COD value from a distance of 25 $\mathrm{m}$ to a distance of $75 \mathrm{~m}$ the pollution value is further away from the point where the lindi pipe leakage at TPA Benowo shows that pollution value is lower at the farther from the leakage point of lindi leaked pipe, its less lindi pollution.

Table 7. Pond Water Quality in the South Location of Lindi leaked Pipe at TPA Benowo.

\begin{tabular}{|l|l|l|l|l|l|}
\hline \multirow{2}{*}{} & \multirow{2}{*}{ Parameter } & \multicolumn{2}{|l|}{$\begin{array}{l}\text { Minister of } \\
\text { Environment }\end{array}$} & \multicolumn{3}{|l|}{ Laboratory Test Results } \\
\cline { 3 - 6 } & & $\begin{array}{l}\text { Regulation } \\
\text { No. 5/2014 } \\
\text { (Group C) }\end{array}$ & C1 & C2 & C3 \\
\hline pH & pH & $\mathbf{6 - 9}$ & $\mathbf{7 , 6}$ & $\mathbf{7 , 6}$ & $\mathbf{7 , 2}$ \\
\hline COD & COD & $200 \mathrm{mg} / \mathbf{l}$ & $\begin{array}{l}\mathbf{7 8} \\
\mathbf{m g} / \mathbf{l}\end{array}$ & $\begin{array}{l}\mathbf{3 3} \\
\mathbf{m g} / \mathbf{l}\end{array}$ & $\begin{array}{l}\mathbf{1 4} \\
\mathbf{m g} / \mathbf{l}\end{array}$ \\
\hline
\end{tabular}

Sources: primary data 2017

The table shows that the water quality of the pond in the South ranged $25 \mathrm{~m}, 75 \mathrm{~m}$, and $150 \mathrm{~m}(\mathrm{C} 1, \mathrm{C} 2, \mathrm{C} 3)$ from the leaking point of lindi pipe TPA Benowo based on water quality classification according to Minister of Environment Regulation No. 5 of 2014 class C are all suitable values from the parameters of $\mathrm{pH}$ and COD. From the corresponding parameters the value decreases with increasing distance from the leaking lindi pipe of the TPA Benowo. 


\section{Impact of Lindi Against Ponds araound the Lindi pipe} leakagepoint of TPA Benowo

The impact of lindi pipe leakage on the pond in the north with a distance of $25-75 \mathrm{~m}$ from the leaking point lindi pipe is quite serious because the pond water is polluted so the life in the pond will die. So the pond can't be used as long as the leak pipe has not been repaired.

Repairing of lindi pipe is still not resolved and then the pond owner asking for losses to the TPA Benowo Management as a compensation over ponds affected by lindi. Ponds from a distance of $150 \mathrm{~m}$ to the south have not experienced the impact of lindi leach pipe because according to the owner of the pond, the fish is still alive and the water is still good for fish farming.

The impact of lindi pipe leakage on the pond in the east at a distance of $25 \mathrm{~m}$, is the same that experienced by the pond in the south at a distance of 25 $\mathrm{m}$, a lot of lindi occured into the pond so that the water turns black then the fish die due to lindi pollution. The pond owner at distance $75 \mathrm{~m}$ to the east also asked for compensation from the TPA Benowo Management altough the impatc is lesser than the distance of $25 \mathrm{~m}$ from lindi leach.

The impact of leaked lindi pipe to the south of the leakage point at a distance of $25 \mathrm{~m}$ is a small percentage of the fish died. Within a long time span of lindi leakage at TPA Benowo unhandled of course the life of fish in the south pond will be worse.For a distance more than $75 \mathrm{~m}$ from the leak point for the south there is no significant impact.

\section{CONCLUSION}

The distribution of lindi pollution around the point of lindi leakage of TPA Benowo is the distance of pond water contaminated with lindi from the lindi pipe leak point after being analyzed descriptively based on data obtained at a distance of $25 \mathrm{~m}, 75 \mathrm{~m}$ and $150 \mathrm{~m}$. The results showed pollution spread as far as $25 \mathrm{~m}$ and $75 \mathrm{~m}$ to the north, a distance of $25 \mathrm{~m}$ to the east from the leak point of lindi pipe of TPA Benowo has occurred lindi pollution while at a distance of $150 \mathrm{~m}$ to the north, at a distance of $75 \mathrm{~m}$ to the east, and distance $25,75 \mathrm{~m}, 150 \mathrm{~m}$ to the south there is no lindi pollution. The farther distance of the pond with the lindi pipe leak from TPA Benowo, is lesser the lindi pollution or the lindi pollution decreases.

\section{ACKNOWLEDGMENT}

This research can be completed with the assistance of FISH UNESA through faculty policy funds in 2017.

\section{REFERENCES}

[1] Kountur Ronny, Metode Penelitian Untuk Penulisan Skripsi dan Tesis. Jakarta: PPM, 2005.

[2] F. G. S. R. H. Pohland, Critical Review And Summary Of Lindi And Gas Production From Landfills. Ohio: U.S Environmental Protection Agency.

[3] Ali. Munawar, Rembesan Air Lindi (Lindi) Dampak pada Tanaman Pangan dan Kesehatan. Jawa Timur, 2011.

[4] J. Priyono, Pemggunaan Batuan Silikat Sebagai Pupuk Rumah Lingkungan. Mataram: Jurusan Ilmu Tanah, Fakultas Pertanian, Univ Mataram, 2008

[5] K. L. H. R. Indonesia, Peraturan Menteri Lingkungan Hidup Republik Indonesia Nomor 05 Tahun 2014 tentang baku mutu air limbah. Jakarta. 